811.163.41'367.625

811.163.41'373.611

https://doi.org/10.18485/sj.2021.26.1.23

ТАњА Ж. ИЛЙ ${ }^{*}$

Универзитет у Београду

Филолошки факултет
Оригинални научни рад

Примљен: 13. 10. 2020.

Прихваћен: 12. 1. 2021.

\title{
ИНТЕРФЕРЕНЦИЈА ТВОРБЕНИХ И СИНТАКСИЧКИХ КОМПОНЕНАТА У ИСКАЗУ
}

У раду се на примерима исказа ексцерпираних из збирке прича „Дорћол” Светлане Велмар Јанковић анализирају префиксални глаголи кретања образовани од мотивног глагола $u \hbar u$ и њихови рекцијски облици. Циљ рада је утврђивање условљености рекцијског облика употребом префикса, те интерференције творбених и синтаксичких компонената. У раду је примењен дескриптивно-семантички метод, те морфосинтаксичка анализа уз елементе компоненцијалне и стилистичке анализе. Анализом грађе дошло се до закључка да је употреба одговарајућег рекцијског облика детерминисана значењем префикса који префигира мотивни глагол $u \hbar u$, реченичним контекстом и природом локализатора.

Кључне речи: исказ, хипосинтакса, ићи, префикс, рекција, перлативност, аблативност, адлативност, језички систем, језик писца.

\section{0. УВОДНА РАЗМАТРАњА}

Циљ рада је да проверимо да ли се остварује интерференција творбеног и синтаксичког плана на нивоу исказа, ${ }^{1}$ односно да ли се префиксом у префиксалним глаголима условљава рекцијски облик, односно модел предлошко-па-

*tanja.ilic.90@gmail.com

${ }^{1}$ Под термином исказ подразумевамо реченицу исказану у конкретној говорној ситуацији, с одређеним комуникативним циљем (Пипер и др. 2005: 25). 
дежне конструкције. За полазну хипотезу узимамо запажање М. Ковачевића према ком „присуство префикса увијек условљава реализацију одређеног типа падежне конструкције, док тај тип падежне конструкције не претпоставља [...] префигирани глагол” (Ковачевић 2015: 70).

Најподеснији за анализу свакако су глаголи кретања, ${ }^{2}$ будући да „највећи број глаголских префикса може префигирати глаголе кретања, а уз то највећи број глаголских префикса има своје формалне и(ли) семантичке еквиваленте у мјесним приједлозима"з (Ковачевић 2015: 60). Стога смо се определили за глагол $u \hbar u$, склон грађењу префиксалних образовања (Ковачевић 2015: 62), и то узевши у обзир само она с рекцијом ${ }^{4}$ у виду предлошко-падежне конструкције с просторним значењем, односно беспредлошког падежног облика. ${ }^{5}$ Ван нашег интересовања остали су глаголи који се допуњују конструкцијом $\partial a+$ презент, зависном реченицом, или они који су у конкретном исказу употребљени без допуне. Такође, нисмо се, услед ограниченог простора, овом приликом бавили имперфективним ликовима истих глагола на -(u)лазити.

Искази су ексцерпирани из збирке прича „Дорћол” С Светлане Велмар Јанковић, која је у електронској верзији доступна на: http://www. antologijasrpskeknjizevnosti.rs/.?

У раду је примењен дескриптивно-семантички метод, те морфосинтаксичка анализа уз елементе компоненцијалне и стилистичке анализе.

\section{1. ОПШТИ ПРИСТУП}

Могуће упориште за постојање саодноса између префикса и предлошко-падежне конструкције налазимо у прилошком пореклу предлога. Наиме, предлози постају од прилога (или прилошких синтагми) одвајањем од глагола, те приближавањем именици, при чему модификују и специјализују њено опште

${ }^{2}$ Предмет наше пажње су глаголи код којих је кретање актуелна и примарна семантичка реализација, што не значи да у исказу они не могу бити употребљени у метафоричком, пренесеном значењу, те реализовати идиоматски или стилистички трансфер значења (в. т. 3.4).

${ }^{3}$ У функцији префикса могу се наћи само предлози који поред просторног прецизирају и друге типове падежних односа (в. Радић 2005: 60, фус. 19).

${ }^{4}$ Термине рекиија и рекиијски облик у овом раду користићемо у синонимном значењу.

${ }^{5}$ Овакве допуне у литератури се називају и спацијалним. Њима се спецификује начин кретања (Брдар 2017б: 129).

${ }^{6}$ Определили смо се ову збирку јер је реч о делу које је, с обзиром на тематику описивања повести Дорћола, најстарије београдске четврти, кроз судбине знаменитих историјских личности, засићено облицима којима се исказују просторна значења. За ову збирку прича Светлана Велмар Јанковић (1933-2014) добила је 1981. г. Андрићеву награду.

${ }^{7}$ Дигитализована издања доступна на овом сајту резултат су пројекта Антологија српске књижевности Учитељског факултета Универзитета у Београду и компаније Microsoft. 
падежно значење. С друге стране, како префикси модификују значења глагола, они тиме заправо преузимају функцију прилога (Драгићевић 2018: 313).

Основе за претпостављени детерминизам пружа и теорија Ј. Куриловича који предлог не сматра самосталном речју, већ морфемом која твори јединство с падежним наставком (према: Граљук 2019: 13).

И србистичка литература успутно се осврће на дати међуоднос. Тако наилазимо на констатацију да ,ако је управна реч у синтагмама са именским изразима који имају просторна значења нека префиксална изведеница, тада се најчешће префиксом управне речи и предлогом у именском изразу означава исти просторни однос" (Пипер и др. 2005: 741; в. нпр. и Пипер 2001:8 72, Пипер/Клајн 2013: 374). А ту су и узгредна запажања Д. Вујовић у вези с префиксима и предлозима исте форме и значења, која се своде на уочавање функције појачавања и наглашавања типа кретања (в. нпр. о префиксу, односно предлогу $y$ : Вујовић 2019: 113).

У вези с наведеним међуодносом има и опречних тумачења. Тако Ј. Радић истиче да ,[...] не постоји ниједна врста једнакости између парадигматских низова типа префикс и предлог: поједини предлози се никада не употребљавају као префикси (нпр. ка, код), као што се и поједини префикси никад не употребљавају као предлози (нпр. про-, раз-)” (Радић 2005: 66). Штавише, постојање датог детерминизма она одриче нарочито у вези с глаголима, наглашавајући да „функционалне везе предлога са префиксом посебно се не могу тражити у вези било ког префикса са глаголским основама [...]”, а аргументујући тај свој став тиме да „граматичка значења префикса и лексичка значења мотивних глагола условљавају широк спектар разлика у типовима значења глагола са истим префиксом" (Исто: 62).

На значај проучавања детерминизма између творбеног форманта и зависног члана синтагме ${ }^{9}$ указао је, дајући допринос осветљењу ове теме, М. Ковачевић (Ковачевић 2015). Он је предочио и да дата тема захвата две дисциплине - творбу речи и синтаксу, обједињене у хипосинтаксу, којој у наших истраживача није придавана већа пажња (Ковачевић 2015: 70; 59).

Значајне прилоге овој проблематици представљају и радови С. Брдар, која је анализирала учесталост и семантику глагола кретања и њихових спацијалних допуна, указујући на сличности и разлике у употреби ових глагола у савременом српском језику спрам језика српске преводне књижевности из

${ }^{8}$ Термине који чине елементе локализације - објекат локализације, локализатор, оријентир - користићемо у значењу које им аутор придаје у истој монографији (Пипер 2001).

${ }^{9}$ М. Ковачевић комбинацију префиксалног глагола и њему одговарајуће рекције посматра као вербалну синтагму с управним чланом у виду префиксалног глагола и рекцијским обликом као зависним чланом (Ковачевић 2015: 60). 
19. в. (Брдар 2017а), односно енглеског језика (Брдар 2016). Њена анализа обухватила је и глаголе брзог кретања (Брдар 2017б).

\section{2. СЕМСКА СТРУКТУРА ГЛАГОЛА ИЋИ И ПРЕФИКСАЛНИХ ГЛАГОЛА У ЧИЈОЈ ЈЕ ТВОРБЕНОЈ ОСНОВИ}

2.1. Прости имперфективни глагол $и ћ и$ припада лексичко-семантичком пољу глагола кретања са значењем човековог самоиницијативног кретања у усправном положају (Вујовић 2012: 86). Мотивни је глагол при грађењу префиксалних глагола који означавају директивно кретање, и то опште - перлативно (кретање које се одвија у правцу прелажења неке путање), и посебно - аблативно (удаљавање од неког оријентира у простору), односно адлативно (приближавање неком оријентиру у простору) (Вујовић 2012: 87).

Основним глаголом $и ћ и$ изражава се архисема 'начин кретања'. Сема усмерености као релевантно семантичко обележје добија се префиксацијом (Вујовић 2019: 37). Префиксима се, дакле, модификује значење основног глагола и изражава конкретнија, релациона сема „усмјереност/правац кретања”. Она обично захтева своју редупликацију у предлогу који је део предлошко-падежне конструкције (Ковачевић 2015: 61-62), будући да „usmerenost glagola kretanja postiže se i sintaksičkim sredstvima, tj. pomoću glagolskih dopuna iskazanih različitim predloško-padežnim konstrukcijama [...] tako što ekspliciraju početnu ili krajnju tačka kretanja ili putanju kretanja i na taj način fokusiraju kretanje na te elemente i lokalizuju ga [...]" (Вујовић 2019: 38, в. и Брдар 2017б: 131). Она се даље разлаже на (архи)семе 'перлативност', 'аблативност' и 'адлативност'. ${ }^{10}$

\section{3. АНАЛИЗА КОРПУСА}

Како бисмо проверили нашу почетну хипотезу и тврђење према ком „што је сема конкретнија, то она јасније указује како на семантички тако и на формални тип падежног мјесног колоката" (Ковачевић 2015: 63), приликом анализе корпуса, те ексцерпираних примера исказа, усмерићемо се на решење неколико мањих задатака. Разврстаћемо префиксе и навешћемо њихова значења. Притом ћемо одредити прототипичне префиксе, ${ }^{11}$ као и префиксе с елементарнијим семама, и истаћи моделе рекцијских облика префиксалних глагола творених поменутим префиксима. Такође, да бисмо утврдили међу-

${ }^{10}$ У циљу терминолошког уједначавања, у даљем току рада служићемо се терминима аблативни, адлативни, перлативни префикси/глаголи и аблативна, адлативна, перлативна рекција.

${ }^{11}$ Под прототипичним префиксима подразумеваћемо оне којима се изражава релациона сема 'усмереност', односно 'правац кретања'. 
однос аспеката језичког система и језика писца, у анализи сваке од група примера, и њихових подврста, даћемо и преглед системских могућности ${ }^{12}$ и упоредићемо их с пишчевим избором.

\section{1. Аблативни префикси}

\subsection{1. ОД-}

3.1.1.1. Знао је само да никако не жели да види Вучића, још мање да оде до њега. (10)

3.1.1.2. Тако је било када је у време Кочине крајине отишао у добровољце или, како се то тада звало, у фрајкоре. (22)

3.1.1.3. Да може, одмах би отишао на Трг, ${ }^{13}$ под споменик Кнезу Михаилу. (23)

3.1.1.4. Вишњић је отишао, сам, у своју ноћ [...] (49)

3.1.1.5. Једном када се, у касну јесен 1797. године припремао да најзад оде на спавање $[\ldots](56)$

3.1.1.6. Кад је, три године после Кнеза, и Господар отишао у изгнанство [...] (80)

\subsection{2. ИЗ-}

3.1.2.1. [...] да други човек изађе из коже а да Стојан завири и под своју. (32) $)^{14}$

3.1.2.2. У тим искушавањима најбоље је ономе ко изађе из живота [...] (50)

3.1.2.3. Ако је из дома руског изасланика изашао са неком тмином у себи [...] (71)

\subsection{3. $C$ -}

3.1.3.1. [...] сиђе са плочника $[\ldots]$ (14)

3.1.3.2. Оно што је желео било је да се не придружи Марку док са београдских капија не сиђу турске страже. (23)

\footnotetext{
${ }^{12}$ Ради утврђивања системских рекцијских облика служићемо се описним једнотомним Речником српског језика Матице српске (РСЈ 2011), иако свесни да их овај речник не бележи све. У њему је глаголска рекција обележена на неколико начина: 1. експлицитно, навођењем заменичких облика у зависним падежима, 2. у склопу дефиниције, 3. посредно, путем примера употребе наведених после дефиниције. На то да се на овај начин могу добити обавештења о глаголској рекцији, упућује и уредник и редактор речника М. Николић у тексту Из предговора претходном издању (РСЈ 2011: 9). У циљу економичности, рекцијске облике илустроваћемо по једним примером.

${ }^{13}$ У исказима с више локализатора истаћи ћемо болдованим фонтом и даље табеларно приказати само рекцију првог, с обзиром на то да он функцију локализатора обавља спрам објекта локализације, док уједно спрам локализатора циља кретања врши функцију објекта локализације (в. и Пипер 2001: 25).

${ }^{14}$ Бројем у загради обележен је број странице с исказом ексцерпираним из извора на који се позивамо.
} 


\subsection{4. ПО-}

3.1.4.1. Кад су [...] пошли Вучићу [...] (10)

3.1.4.2. Марио је кад је Милош, убрзо, пошао у изгнанство. (14)

3.1.4.3. [...] пође средином коловоза, ка Вишњићевој. (14)

3.1.4.4. [...] одлучује се да ли да пође лево, краћим делом своје улице, ка Вишњићевој, или десно, дужим делом, ка Француској. (18)

3.1.4.5. [...] пошао ка Капетан-Мишином здању [...] (24)

3.1.4.6. Сад се, од двадесетпеторице, издвоје седморица и пођу на зидине. (27)

3.1.4.7. [...] а он пође ка Стамбол-капији. (28)

3.1.4.8. Узун Мирко се опет спушта у гунгулу Велике пијаце [...] пође Цариградским путем, према Стамбол-капији. (30)

3.1.4.9. [...] наговори Проту Матеју Ненадовића да пођу на преговоре са Турцима, у турски крај, преко Дрине. (34)

3.1.4.10. И Стојан Чупић пође натраг, међу Србе, а Прота остане међу Турцима. (35)

3.1.4.11. Тако, у пратњи оних који су му вест и донели, пође на Прудине. (37)

3.1.4.12. Добрача је, кроз ту пустош, пошао узбрдо, ка Стамбол-капији. (40)

3.1.4.13. Чим се пође наниже, према завршетку Симине улице и према некадашњој Великој школи [...] (45)

3.1.4.14. Пошао им је у сусрет. (49)

3.1.4.15. Али, ако том улицом [...] ипак пођете узбрдо, од Душанове [...] (52)

3.1.4.16. У Бечу, све је пошло још боље. (56)

3.1.4.17. Почело је да свиће а она је, боса пошла преко тла [...] (59)

3.1.4.18. [...] светлосни трептај је пошао из ње па застао [...] (60)

3.1.4.19. Пошли су на излет. (61) корак. (62)

3.1.4.20. [...] али Кнегиња, чим пође низ дунавску падину, заиста убрзава

3.1.4.21. [...] он да би требало да пође десно, Улицом Браће Југовића, све до своје, Доситејеве улице [...] (70)

3.1.4.22. Пошао је на пут у Влашку [...] (72)

3.1.4.23. Кад је пошао у Букурешт [...] (72)

3.1.4.24. [...] пошао је, са малом уштеђевином, на чувену београдску марвену пијацу $[. .].(76)$

3.1.4.25. Када је Кнез изгнан, Анастасијевић је пошао на још дужа путовања. (80) 


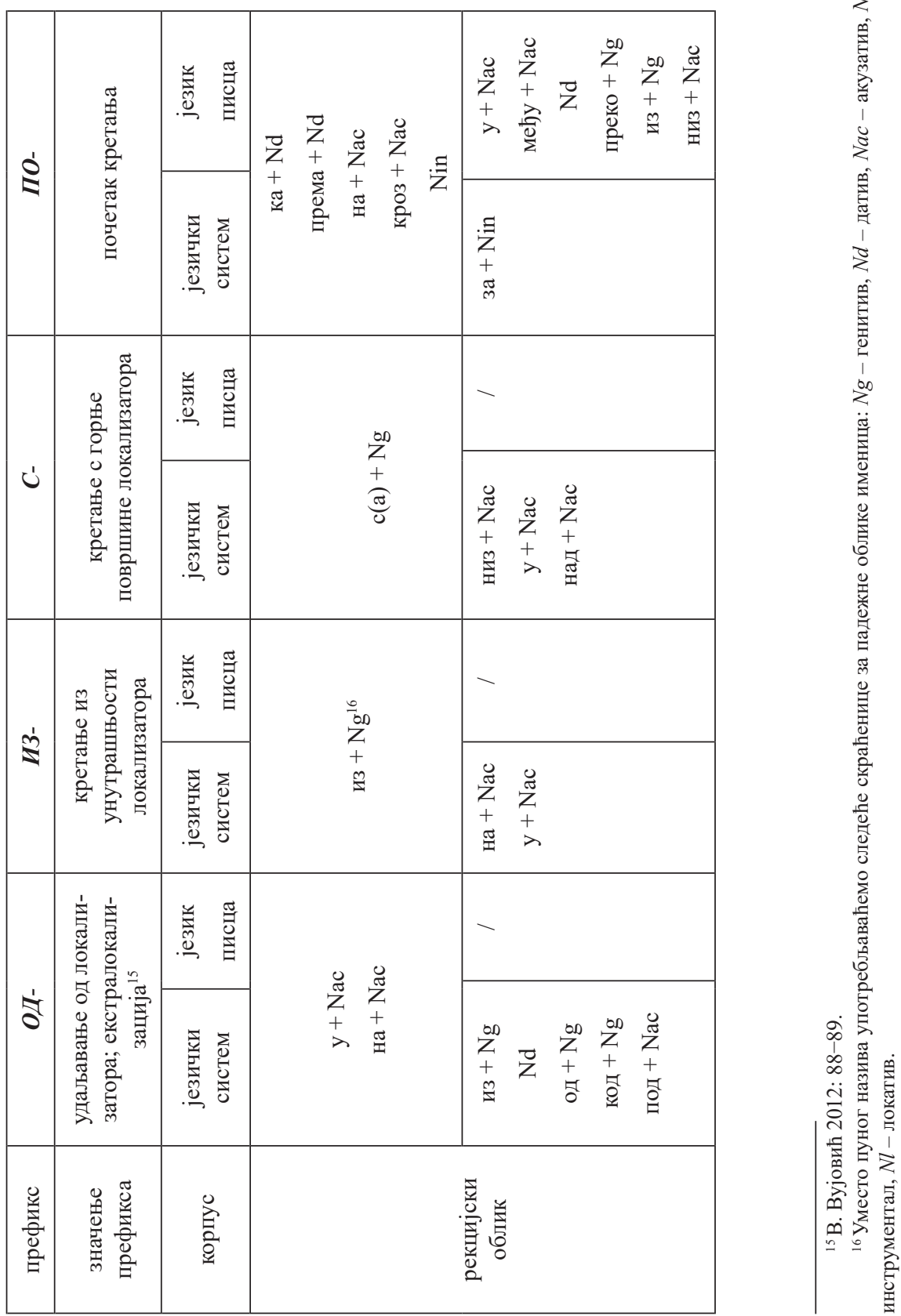


Прототипични аблативни префикс је од-. ${ }^{17}$ Сходно израженој семи 'удаљавање', он условљава семантички тип предлошко-падежне конструкције (Ковачевић 2015: 67). Адлативне рекције $y+N a c$ и на + Nac заједничке су и језичком систему и језику писца. Уз то, језички систем пружа пример аблативне рекције $о \partial+N g$, којом се идентификује почетна тачка кретања. Језички систем доноси и модел аблативне рекције из $+N g$ ('удаљавање од унутрашњости локализатора с обимом', Ковачевић 2015: 66) и више модела адлативне рекције: $N d$ ('усмереност ка локализатору', Пипер и др. 2005: 190), код + Ng ('просторно-социјативно значење', Пипер 2001: 79) и под + Nac ('кретање доњом страном локализатора'). ${ }^{18}$ Адлативна рекција је могућа ако се има у виду шири реченични контекст, одакле се може идентификовати почетна тачка кретања (Вујовић 2019: 41). ${ }^{19}$

У примеру 3.1.2.3. префиксом из- актуелизује се сема 'напуштање неког простора'. Он стога захтева предлошко-падежну конструкцију с редуплицираним предлогом, што је модел потврђен у оба корпуса, а у језику писца и једини (уп. и метафоричну употребу глагола изаћи у примерима 3.1.2.1. и 3.1.2.2, в. т. 3.4). Језички систем допушта и могуће адлативне рекције нa $+\mathrm{Nac}$, односно $y+N a c$ кад се претпоставља циљ кретања. ${ }^{20}$

Префикс c-, у ком у датим примерима доминира сема 'премештање с вишег на ниже место', захтева формалну и семантичку редупликацију (Ковачевић 2015: 66-67), за шта потврде дају оба корпуса. Системске могућности јесу и перлативна рекција низ + Nac ('кретање доњом страном локализатора'), те адлативне $y+N a c$ ('кретање унутрашњошћу локализатора') и над + Nac ('кретање горњом страном локализатора'). ${ }^{21}$

Највећи и најразноликији број рекцијских облика допуњује глагол префигиран префиксом по-, што одговара природи његовог инхоативног значења. Дакле, будући да не предодређује ни семантички ни формални тип предлошко-падежне конструкције, с њим је могуће употребити било коју предлошко-падежну конструкцију с просторним значењем ${ }^{22}$ (Ковачевић 2015: 69). У оба корпуса поклапају се синонимни ${ }^{23}$ модели $к a+N d$ и премa $+N d$, затим нa $+N a c$, што су адлативне рекције, и кроз + Nac и Nin као перлативне.

\footnotetext{
${ }^{17}$ И Д. Вујовић наводи глагол отићи као типични аблативни (Вујовић 2019: 39).

${ }^{18}$ Исп. нпр. отићи из куће; кући; на пут; од куће; код лекара; у град; под лед (РСЈ 2011: 882).

${ }^{19}$ Предлошко-падежна конструкција отуда илуструје синтаксичко-семантичку компресију (Ковачевић 2015: 69).

${ }^{20}$ Исп. нпр. изаћи из собе; на вечеру; у шетғу (РСЈ 2011: 431).

${ }^{21}$ Исп. нпр. сићи с планине; низ степенище; у беду; [Вече је сишло] над Париз (РСЈ 2011: 1202).

${ }^{22}$ Из тог разлога нећемо, као у другим примерима, наводити значења свих рекцијских облика, сем најфреквентнијих.

${ }^{23}$ Предлози ка и према употребљавају се као синонимни у комбинацији с просторним дативом у значењу динамичке усмерености (Пипер/Клајн 2013: 352).
} 
Језички систем нуди још једино модел адлативне рекције за $+\mathrm{Nin}^{24}$ за разлику од језика писца с више модела: $y+N a c$, међy $+\mathrm{Nac}, \mathrm{Nd}$, nреко $+\mathrm{Ng}$, из $+N g$, низ + Nac. У језику писца је пак најучесталија рекција нa + Nac, која се употребљава:

- ако је циљ кретања отворен простор (Брдар 2017б: 135): в. т. 3.1.4.24;

- уз именице које именују топониме или просторије које се налазе релативно високо (Пипер и др. 2005: 728): в. т. 3.1.4.11, односно 3.1.4.6;

- ако се место кретања налази или кретање завршава на површини / горњој страни, односно изнад и поред чега, у функцији одредбе за место, при чему се у функцији циља кретања могу наћи и апстрактни појмови (Стевановић 1991: 408-410): в. т. 3.1.4.9, 3.1.4.19, 3.1.4.22. и 3.1.4.25. Притом, у примерима 3.1.4.19, 3.1.4.22. и 3.1.4.25. рекцијским допунама је инхерентна месна семантика, док је у примеру 3.1.4.9. циљ кретања тек накнадно одређен одредбом за место.

Од беспредлошкох облика доминира Nin - просекутив, у значењу 'кретање/простирање ширим простором, или простором за кретање људи' (Пипер/Клајн 2013: 384), односно 'кретање дужином локализатора' (Пипер и др. 2005: 729-730). У исказима је обично употребљен с локализатором циља кретања, који у свим нашим примерима има адлативну рекцију (в. т. 3.1.4.3, 3.1.4.4, 3.1.4.8, 3.1.4.21), с изузетком једног с аблативном рекцијом (в. т. 3.1.4.15).

\section{2. Адлативни префикси}

\subsection{1. ДО-}

3.2.1.1. [...] а он је, на Врачару, чекао да му дође и Господар Јеврем. (10)

3.2.1.2. [...] па се умеша међу децу што излазе из школе, и [...] дође до Калемегдана. (14)

3.2.1.3. [...] дошли су до терзијине мале радње [...] (19)

3.2.1.4. Више није дошао у Беч иако је, марвени трговац, много путовао. (39)

3.2.1.5. Као да је нагло дошао до себе [...] (45)

3.2.1.6. Када по подне дође у своју улицу [...] (58)

3.2.1.7. [...] Доситеј је разабрао да је дошао до оне границе разумевања са које одлазак из живота изгледа без значаја [...] (68)

3.2.1.8. [...] на згради коју је купио чим је дошао у Београд [...] (71)

3.2.1.9. Понекад Капетан Миша дође на Студентски трг. (81)

\subsection{2. $y$ -}

3.2.2.1. Кад су, за Аустријанцима, Турци поново ушли у Београд [...] (4)

3.2.2.2. [...] једини који је смео да му уђе под шатор изненада [...] (21)

${ }^{24}$ Исп. нпр. поћи према кући; ка уједињењу; на Турке; руком; кроз народ; за пријатељем (PCJ 2011: 975). 
3.2.2.3. [...] у манастирску трпезарију ұшла је, дакле, Љубица и упутила се полако, корак по корак, према Господар-Милошу, тамо, у дну собе. (62)

3.2.2.4. Искушење је ушло право у њен Конак [...] (63)

3.2.2.5. Доситеј је, чим је ушао у свој дом [...] (71)

\subsection{3. $H A-$}

3.2.3.1. Доситеј је то наслућивао само није разазнавао са које ће стране наићи промена. (70)

3.2.3.2. Наишла је са стране непознатог. (70)

\subsection{4. $3 A-$}

3.2.4.1. Крочи на Брег за размишљање, зађе у сенке и наслони образ уз једно дрво [...] (15)

3.2.4.2. [...] кад зађе у онај део улице што се [...] спушта ка Дунаву [...] (58)

3.2.4.3. [...] само што се зађе у Улицу Змаја од Ноћаја, постаје још уже [...] (34)

Прототипични адлативни префикс је до-. Како у примерима 3.2.1.1, 3.2.1.2, 3.2.1.3, 3.2.1.4, 3.2.1.6, 3.2.1.8, 3.2.1.9. изражава сему 'доспевање до одређеног места', он условљава само семантички тип предлошко-падежне конструкције, што је сагласно са забележеним разноликим рекцијским моделима. Доминантна је пак у оба корпуса формална редупликација, оличена моделом $\partial o+N g$, уз $y+N a c$ и нa $+N a c$. Језички систем нуди још модела адлативних рекција пред + Nac ('кретање предњом страном локализатора'), $y+N l$ ('разноусмереност', Ковачевић 2015: 63-64) и под + Nac ('кретање доњом страном локализатора'), ${ }^{25}$ као и пример аблативне рекције $u з+N g$. У језику писца је употребљена адлативна рекција - $N d$.

Префикс $y$-, те у примерима из корпуса доминантна сема 'доспевање у унутрашњост нечега', потврђује учесталу формалну и семантичку редупликацију (Ковачевић 2015: 67-68). Језик писца пружа модел више у односу на језички систем, ${ }^{26}$ и то такође адлативну рекцију под $+\mathrm{Nac}$.

У језичком систему се наићи комбинује с адлативним рекцијама на + Nac ('ненадана појава локализатора на путу', Ковачевић 2015: 68) и $y+N a c$ ('циљ кретања је унутрашњост локализатора'). ${ }^{27}$ У језику писца, где се префиксом изражава сема 'наилазак на нешто', он је пак у комбинацији с моделом просторног генитива $c a+N g$, ,У функцији спацијалног детерминатора аблативног типа” (Пипер и др. 2005: 137, в. и Пипер/Клајн 2013: 340), којим се обележава отворен простор (Брдар 2017б: 135). Дакле, уз префикс на- употребљавају се адлативне рекције у језичком систему, те аблативна у језику писца, што можемо довести у везу с избором локализатора.

\footnotetext{
${ }^{25}$ Исп. доћи пред кућу; из Америке; на састанак; до средине пута; у искушење; у деоби; под руку (РСЈ 2011: 298).

${ }^{26}$ Исп. нпр. ући у собу (РСJ 2011: 1394).

${ }^{27}$ Исп. нпр.: наићи: на очи/некога; у наш логор (РСЈ 2011: 754).
} 


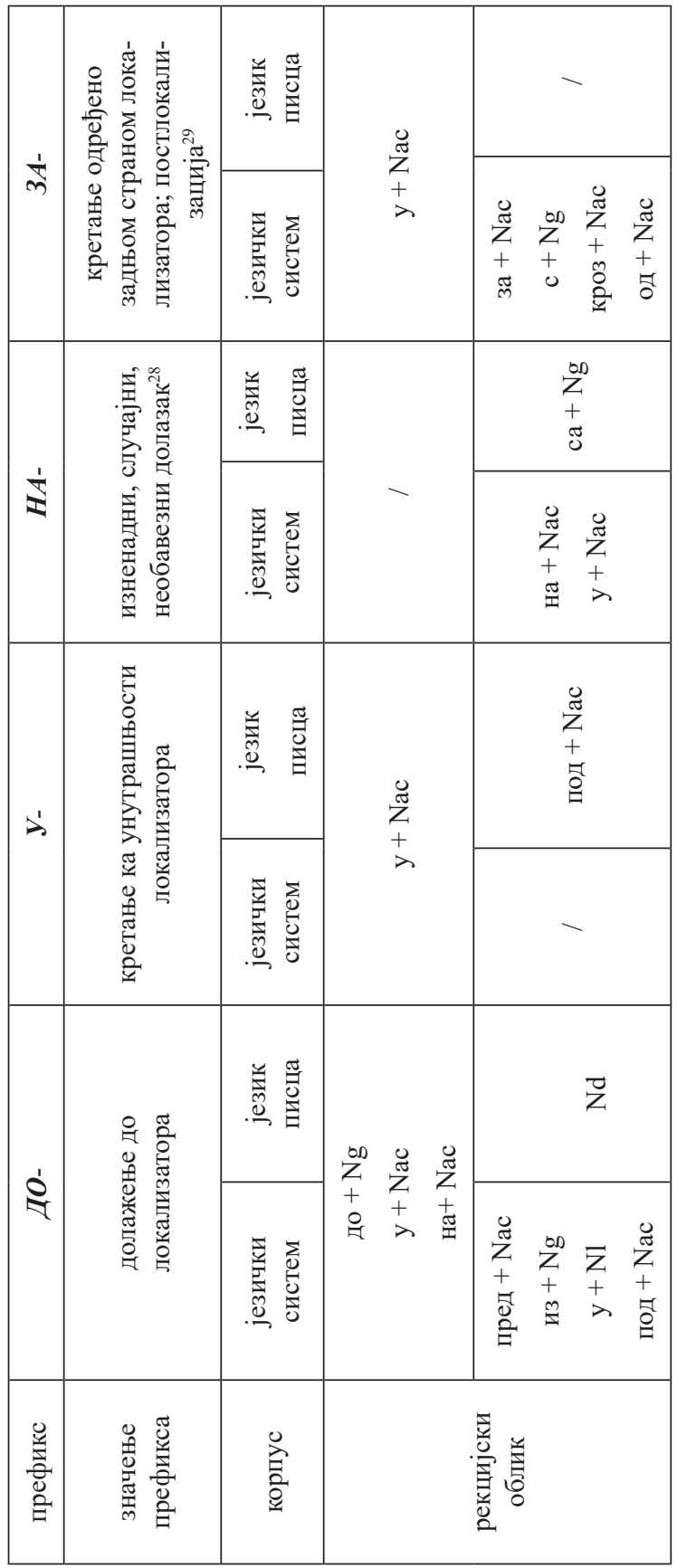


Кад је у питању адлативни префикс за-, очекиван би био модел који обједињује формалну и семантичку редупликацију, будући да се префиксом за- и у ексцерпираним примерима актуелизованом семом 'доспевање са друге стране нечега' спецификује тип адлативног значења. Међутим, корпуси доносе модел $y+N a c$, сходно томе што је циљ кретања унутрашњост локализатора. Језички систем садржи још један пример адлативне рекције за + Nac ('кретање задњом страном локализатора'), затим аблативне $c+N g$ и $о \partial+N g$, те перлативне рекције кроз + Nac ('пресецање унутрашњег простора', Пипер/Клајн 2013: 373). ${ }^{30}$

\section{3. Перлативни префикси}

\subsection{1. ПРЕ-}

3.3.1.1. Када пређе Капетан-Мишину улицу [...] (14)

3.3.1.2. [...] никако да пређе тих неколико корачаји [...] (23)

3.3.1.3. До Стамбол-капије требало је прећи [...] још онај мањи део улице трг и целу Васину. (27)

3.3.1.4. Тај пут који се данас пређе за неколико минута [...] (27)

3.3.1.5. А онда, кад се пређе угао Седмог јула и стигне до Улице цара Уроша [...] (29)

3.3.1.6. Мачва је била утихла од свега што је прешло преко ње [...]

3.3.1.7. [...] кад јутарња измаглица пређе и преко облака и преко асфалта [...] (38)

3.3.1.8. Вишњић се припрема да [...] пређе, кратком низбрдицом, до Музеја [...] (50)

3.3.1.9. Трептај задовољства, врхунског и безумног као да је љубавно, прешао је свим ивицама његовог бића. (54)

\subsection{2. ПРО-}

3.3.2.1. [...] када је, децембра 1918, држећи стројеви корак, Позоришном ка Теразијама и Народној скупштини прошла почасна чета наших савезника, Француза. (6)

3.3.2.2. Прошли су, непримећени, поред турског хана [...] (27)

3.3.2.3. Увече, док је та жена узета у испомоћ као и обично размештала Господареву постељу, наишла је Љубица, прошла поред ње [...] (61)

\footnotetext{
${ }^{30}$ Исп. нпр. заћи за кућу; с пута; кроз планину; у шуму; од куће (до куће) (РСJ 2011: 404).
} 


\begin{tabular}{|c|c|c|c|c|}
\hline префикс & & & & \\
\hline $\begin{array}{c}\text { значење } \\
\text { префикса }\end{array}$ & $\begin{array}{r}\text { кретање г } \\
\text { ло }\end{array}$ & $\begin{array}{l}\text { површином } \\
\text { ора }^{31}\end{array}$ & кретање п & лизатора ${ }^{32}$ \\
\hline корпус & $\begin{array}{c}\text { језички } \\
\text { систем }\end{array}$ & $\begin{array}{l}\text { језик } \\
\text { писца }\end{array}$ & $\begin{array}{c}\text { језички } \\
\text { систем }\end{array}$ & $\begin{array}{l}\text { језик } \\
\text { писца }\end{array}$ \\
\hline \multirow{2}{*}{$\begin{array}{c}\text { рекцијски } \\
\text { облик }\end{array}$} & \multicolumn{2}{|c|}{$\begin{array}{c}\mathrm{Nac} \\
\text { преко + } \mathrm{Ng} \\
\mathrm{Nin}\end{array}$} & \multicolumn{2}{|c|}{$\begin{array}{c}\text { поред + Ng } \\
\text { Nin }\end{array}$} \\
\hline & $\begin{array}{c}\mathrm{y}+\mathrm{Nac} \\
\text { на }+\mathrm{Nac} \\
\mathrm{y}+\mathrm{Nl}\end{array}$ & / & $\begin{array}{c}\text { кроз + Nac } \\
\mathrm{Nac} \\
\text { по + N1 } \\
\text { мимо + Ng } \\
\text { крај + Ng }\end{array}$ & / \\
\hline
\end{tabular}

\section{Прототипични перлативни префикси су пре- и про-..33}

Префикс пре- тражи модел преко $+N g$ (Ковачевић 2015: 64), ког има у оба корпуса, поред Nac и Nin. Међутим, како префикс пре- транзитивизује мотивни глагол, очекивано је њему синониман ${ }^{34}$ рекцијски облик Nac најзаступљенији (в. и Ковачевић 2015: 64). Он има, дакле, перлативно значење у комбинацији са значењем локализованости површином локализатора (Пипер и др. 2005: 730). Происходи да се у језику писца префиксом актуелизује сема 'кретања с једне стране нечега на другу, кроза што'.

У језичком систему су могуће рекције глагола прећи још $\mathrm{Ha}+\mathrm{Nac}$ у вези с апстрактним кретањем, односно $y+N a c$ уз претпостављену почетну тачку кретања, и $y+N l$ при кретању које се одвија у више праваца. ${ }^{35}$

${ }^{31}$ За Д. Вујовић овај префикс има значење праволинијског преласка површине локализатора с једног на други крај (Вујовић 2019: 114).

${ }^{32}$ Притом, ирелавантно је да ли се кретање с једног на други крај локализатора одвија његовом површином, унутрашњошћу, дуж, око, изнад или испод њега (Вујовић 2019: 100). М. Ковачевић уже одређује значење овог префикса као ,једноусмјерено кретање унутрашњошћу” (Ковачевић 2015: 64).

${ }^{33}$ Д. Вујовић наводи само глагол прећи као типични перлативни глагол (Вујовић 2019: 40).

${ }^{34}$ „Просторно значење предлошко-падежне конструкције је и у просторном акузативу, као и у употреби других падежа у просторном значењу, умногоме одређено значењем управне речи, поготову значењем њеног префикса, што омогућава и такве односе синонимије какви постоје између беспредлошког акузатива и предлошког генитива, нпр. прећи улииу и прећи преко улице и сл.” (Пипер/Клајн 2013: 374).

${ }^{35}$ Исп. нпр. прећи какав простор; у нову кућу; на друге; преко образа [руменилом]; оком; у глави (РСЈ 2011: 1014). 
Префикс про- захтева модел кроз + Nac (Ковачевић 2015: 64), са значењем пресецања унутрашњег простора (Пипер/Клајн 2013: 373), односно кретања површином, (Пипер и др. 2005: 729), за шта језик писца не пружа потврда. Оба корпуса садрже рекцијске облике поред $+N^{36} u$ Nin, а језички систем, поред већ поменутих облика, и $\mathrm{Nac}, n o+N l$, мимо/краj $+N g,{ }^{37}$ којим се моделима потврђује да „za osnovno određivanje perlativnosti kao kriterijum uzimamo prelazak preko površine lokalizatora, mada [...] perlativnu koncepciju kretanja predstavljaju i glagoli koji označavaju prolazak kroz unutrašnjost lokalizatora kao i prolazak pored lokalizatora ili oko lokalizatora” (в. Вујовић 2019: 40, фус. 21).

\section{4. Напомене о стилској вредности језика писца}

Сходно нашем избору корпуса, те опредељености за збирку прича, односно наративне текстове, очекивана је висока фреквенција глагола кретања. Притом, већина ексцерпираних примера реализује спацијалну семантику, што их чини стилски немаркираним. Одређени префиксални глаголи у нашем корпусу поред конкретног кретања означавају и апстрактно, кад су у функцији циља кретања апстрактне или глаголске именице.

Тако поједини глаголи кретања у контексту реализују пренесено, метафорично значење. То је, рецимо, случај с глаголом доћи. Тако у примеру 3.2.1.5. активирањем префиксалне семе 'доспевање до нечега' реализује се значење 'освестити се, прибрати се', чиме се остварује идиоматски трансфер значења. У примеру 3.2.1.7, те у конструкцији с до + генитив, остварује се пак значење 'схватити'.

И глагол изаћи у примерима 3.1.2.1. и 3.1.2.2 не одражава примарно спацијалну семантику, већ се актуелизовањем префиксалне семе 'одвајање' мења основни смисао целог исказа. Стога се конструкција изаћи из коже користи у значењу 'постати друкчији', односно конструкција изаћи из живота еуфемистички је употребљена уместо глагола 'умрети'.

Забележене конструкције с пренесеним значењем доприносе сликовитом представљању емоционалног стања јунака.

${ }^{36}$ Исп. „[...] уколико управни глагол има префикс про-, перлативно значење се не мења, али уместо семантичке компоненте 'површина' конструкција има семантичку компоненту 'унутрашњост', нпр. проћи тунел, са истим просторним значењем као проћи кроз тунел, али и са могућношћу интерпретације као да је у питању конструкција проћи поред тунела. У конструкцијама које се односе на локализаторе са слабије израженом унутрашњом страном то је и једина могућност интерпретације, нпр. проћи саобраћајни знак, проћи станииу, проћи паркинг и сл." (Пипер и др. 2005: 730).

${ }^{37}$ Исп. нпр. проћи кроз ходник; лицем; поред банке; Врање; по народу; мимо (поред, крај) некога (РСJ 2011: 1063). 
Такође, колокабилност одређених глагола с појединим рекцијама можда можемо уврстити у идиолекатске специфичности. Наиме, премда језички систем нуди разнолике рекцијске могућности, глагол наићи комбинује се само ca $c(a)+N g$, а заћи само са $y+N a c$.

\section{4. ЗАКљУЧАК}

Србистичка се литература експлицитно не бави хипосинтаксичком проблематиком. Хипосинтакса, међутим, показује да су просторна значења предлошко-падежних конструкција умногоме одређена значењем префикса.

У овом раду смо настојали да утврдимо интерференцију творбе речи и синтаксе унутар исказа, поредећи стање у српском језику као језичком систему (на основу корпуса РСЈ) са стањем у језику једнога писца - Светлане Велмар Јанковић, с циљем утврђивања специфичности реализације датог творбено-синтаксичког међуодноса с обзиром на међуоднос језичког система и конкретног књижевног дела. Свесни смо пак да у вези с рекцијским облицима нису прибележене све могућности, и да то вероватно није ни могуће чак и са богатијим корпусом јер ти облици услед језичког развоја подлежу сталној актуелизацији.

Очекивано више рекцијских облика бележи РСJ, с изузетком глагола префигираних префиксима по- и $y$-, где језик писца пружа више модела.

На основу проведеног истраживања може се извести неколико закључака.

Пошто су значења прототипичних префикса апстрактна, тип кретања индивидуализује се предлошко-падежном конструкцијом као одразом диференцијалних сема. Отуда префикси захтевају само семантичку редупликацију, не нужно и формалну. С друге стране, префикси обележени конкретним, диференцијалним семама условљавају најчешће и формалну и семантичку редупликацију, дакле одређен тип рекције.

Формална редупликација се, на основу анализираног корпуса, остварује

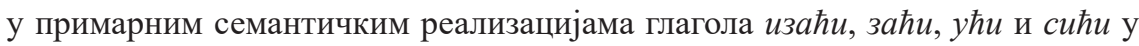

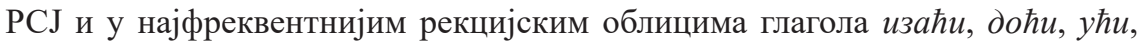
сићи у језику писца.

И на семантичком плану прожимају се творбени и синтаксички план. Сема усмерености добијена додавањем префикса на мотивни глагол $u \hbar u$ редуплицира се предлогом у склопу рекцијских облика, што потврђују примери рекција заједничких и језиком систему и језику писца, дакле - типичних. Те тако аблативним префиксима одговарају аблативне рекције, што је случај с префиксима из- и $c(a)$-. Префикс од- прате адлативне, што је разумљиво, јер се 
њима прецизира завршна тачка кретања. ${ }^{38}$ Уочена висока фреквенција адлативних рекција можда се може објаснити „људском концепцијом кретања у којој је много значајније истаћи циљ свог кретања него тачку са које је започето" (Брдар 2017б: 131). Аблативни префикс по- одступа у погледу адлативних и перлативних рекција, мада је његова аблативност упитна (в. Матовац 2018: 207-208), а природом свог значења не условљава ни семантичку ни формалну редупликацију. Адлативне префиксе следе адлативне рекције код свих префикса (до-, $y$-, за-), сем у случају префикса $н a-$, где језички систем одликује адлативна рекција а језик писца аблативна. Перлативни префикси пре- и продоследно траже перлативне рекције.

Такође, одређене предлошко-падежне конструкције с просторним значењем никако се не могу употребити уз глагол $u \hbar и$ кад му се придода одређени префикс - уз изаћи се не може употребити код $+N g$, нити уз сићи над $+N i n$, као ни уз ући по + Nac итд.

Из свега реченог као закључак следи да је употреба одговарајућег рекцијског облика условљена значењем префикса који префигира мотивни глагол $u \hbar u$, реченичним контекстом који пружа податак о тачки кретања и природом локализатора.

\section{Извор}

Јанковић: Светлана Велмар Јанковић, Дорћол, Београд: Учитељски факултет.

\section{ЛИТЕРАТУРА}

Брдар 2016: Сања Брдар, Глаголи кретања у српском и њихови енглески еквиваленти у роману Руски прозор Драгана Великића, Zbornik za jezike i književnosti Filozofskog fakulteta u Novom Sadu, 6, 11-50.

Брдар 2017a: Сања Брдар, Анализа глагола кретања у језику Прве књиге Мојсијеве, Religija i tolerancija, XV/27, 83-106.

Брдар 2017б: Сања Брдар, Реченични модели с глаголима брзог кретања, Прилози проучавању језика, 48, 127-160.

${ }^{38}$ Исто је и у исказима с два локализатора, где је први у двојакој функцији - локализатора објекту локализације, али и објекта локализације другом локализатору. Другим локализатором прецизира се тачка кретања, у зависности од чега он има аблативну или адлативну рекцију. Нека будућа истраживања могла би дубље осветлити ову проблематику, будући да смо се ми за потребе овог рада детаљније бавили само првим локализатором. 
Вујовић 2012: Душанка Вујовић, Основна значења и префиксална деривација глагола ићи и ходати, Зборник Матище српске за филологију и лингвистику, LV/2, 85-92.

Вујовић 2019: Dušanka Vujović, Glagoli ljudskog kretanja u savremenom srpskom jeziku - semantika i derivacija, Novi Sad: Filozofski fakultet.

Граљук 2019: Silvija Graljuk, Prijedlozi s genitivom u ukrajinskom i hrvatskom jeziku (doktorska disertacija), Zagreb: Sveučilište u Zagrebu.

Драгићевић 2018: Рајна Драгићевић, Српска лексика у прошлости и данас, Нови Сад: Матица српска.

Ковачевић 22015 : Милош Ковачевић, Префиксација и њен утицај на форму и семантику синагме, Кроз синтагме и реченище, Београд: Јасен, $59-70$.

Матовац 2018: Darko Matovac, Glagoli kretanja i prefiks po- u hrvatskom, Croatica: časopis za hrvatski jezik, književnost i kulturu, XLII/62, Zagreb, 205-219.

Пипер 22001: Predrag Piper, Jezik i prostor, Drugo dopunjeno izdanje, Beograd: Čigoja - XX vek.

Пипер и др. 2005: Синтакса савременога српског језика: проста реченица (у редакцији Милке Ивић), Београд - Нови Сад: Институт за српски језик САНУ - Матица српска.

Пипер/Клајн 2013: Предраг Пипер, Иван Клајн, Нормативна граматика српског језика, Нови Сад: Матица српска.

Радић 2005: Јованка Радић, Префиксална творба речи - деривација или композиција (наставни и ваннаставни аспект), Наш језик, XXXVI/1-4, $54-67$.

PCJ 2011: Речник српскога језика, Нови Сад: Матица српска.

Стевановић ${ }^{5}$ 1991: Михаило Стевановић, Савремени српскохрватски језик (граматички системи и књижевнојезичка норма), II, Београд: Научна књига. 


\section{INTERFERENCE OF WORD-FORMATION AND SYNTACTIC COMPONENTS IN A STATEMENT}

\section{Summary}

In this paper, we have sought to determine the interference of word formation and syntax within statements comparing the situation in the Serbian language as a language system with that of a writer - Svetlana Velmar Janković. We analyzed the prefixed verbs of motion formed by the motive verb to go and their rection forms to determine the conditionality of the rection form by the use of prefixes.

Since the meanings of the prototypical prefixes are abstract, the type of motion is individualized by the prepositional case construction as a reflection of differential semes. Therefore, prefixes require only semantic reduplication, not necessarily formal, while prefixes marked with specific, differential semes condition most often both formal and semantic reduplication, that is, a particular type of rection.

The directivity seme obtained by adding the prefix to the motive verb to go is reduplicated by the preposition within the rection forms, as evidenced by the examples of the rections common to both the language system and the writer's use of language. Ablative rections correspond to ablative prefixes, except in the case of prefix $o d$ - followed by adlative ones, since they specify the endpoint of motion and prefix po-, which, by the nature of its meaning, conditions neither semantic nor formal reduplication. Adlative prefixes are followed by adlative reactions in all prefixes except in the case of prefix na-, where the language system and the writer's use of language are characterized by an adlative and ablative rection, respectively. This observation may concern the possible colocability of certain verbs with particular rections in the writer's use of language. Perlative prefixes pre- and pro- consistently seek perlative rections.

Also, certain prepositional case constructions with spatial meaning cannot be used with the verb to go when a specific prefix is added to it.

It can be inferred that the use of a proper rection form is conditioned by the meaning of the prefix that prefigures the motive verb to go, the sentence context that provides information about the point of motion, and the nature of the localizer.

Keywords: statement, hyposyntax, to go, prefix, rection, perlativity, ablativity, adlativity, language system, writer's use of language. 